\title{
Lecturers' Productivity in Private Universities, Kazakhstan
}

\author{
Mahiswaran Selvanathan ${ }^{1, *}$, Dontsov Yan $^{2}$, Mahadevan Supramaniam ${ }^{3}$, Thilageswary Arumugam², \\ Subaashnii Suppramaniam ${ }^{2}$ \\ ${ }^{1}$ National Higher Education Research Institute (IPPTN), Universiti Sains Malaysia (USM), Malaysia \\ ${ }^{2}$ Asia Pacific University of Technology \& Innovation (APU), Malaysia \\ ${ }^{3}$ SEGi University, Malaysia
}

Received July 14, 2019; Revised October 9, 2019; Accepted November 14, 2019

Copyright $\mathrm{O} 2019$ by authors, all rights reserved. Authors agree that this article remains permanently open access under the terms of the Creative Commons Attribution License 4.0 International License

\begin{abstract}
The productivity levels of lecturers and what causes an increase or decrease in them have been the subjects of debate and concentration among academics, practitioners and researchers for many decades. This makes it more volatile because of the complex nature of the numerous different industries involved. In the education industry itself for example, there have been numerous antecedents which have been found to have an effect on productivity levels. The aim of this research is to identify the factors and assist in closing the gaps of knowledge in increasing lecturer productivity, especially in the private universities. The main purpose of this study was to identify the significant relationship of work-life balance, job responsibility, competency, motivation and professionalism on lecturer productivity in private universities Kazakhstan. Hypotheses created to support these objectives results indicated that all tested independent variables have significant relationship with lecturer productivity except for no significant relationship indicated for competency and professionalism based on correlation analysis. This study considers these antecedents on lecturer productivity in the Private universities being the fastest growing industry in Kazakhstan. This implies that the organizational human resource policies may need a re-look on creating better benefits, lecturer assistance program, job design, training and development and organizational culture. These findings suggest that in this complex and dynamic environment, lecturer productivity is a means of organizational success and sustainability.
\end{abstract}

Keywords Lecturer Productivity, Corruption, Trade Openness, Political Stability, BRIC Countries

\section{Background of the Study}

One of the important factors affecting the productivity of lecturers in a university is Lecturers' Attitude. It's not a secret in any university. There is competition between lecturers, so one lecturer tries to extrude the other, thereby creating a conflict of interests within the university Luft (2016). Often, many companies cooperate with psychologists and personal relations trainers within the organization. However, this problem of competition is created by the leaders themselves, putting tough conditions and encouragement for one or several lecturers under the fulfilled work plan. This university structure has its shortcomings, because the lecturer after a failure in this or that sphere will no longer be productively tuned to the next task in connection with ignoring his successes in the past. Certainly, competition within the university takes place and it is for the analysis of the productivity of each lecturer and the identification of not competent lecturers in the universities. Thus, creating a competition within the university, the leader is obliged to monitor and correct the work process, so that a high level of lecturer productivity takes place during the entire work process, rather than individual projects.

The attitude of the lecturers is based on the established order within each university. Of course, the universities can be compared with the Swiss Watch mechanism, where each element depends on the performed action of the other element, thereby creating a workflow in which each lecturer has accountability for a particular job. Lecturer Accountability has a huge impact on the Lecturers' Attitude to achieve success in any organization Mackay, (2016). Each lecturer has his own responsibilities, for which he is responsible for their implementation or not performing. Thus, lecturers work together, share ideas and accountability and create an integrated success strategy for the universities. From this, it follows that the attitude of lecturers is based on factors within a particular universities and is undoubtedly the responsibility of each universities 
too. In addition, according to Shah, Irani and Sharif (2016), the impact of organizational changes on the attitude of lecturers at Pakistan universities, a survey of 556 lecturers was conducted. Thus, $32.67 \%$ need changes in the organization as a whole and $67.33 \%$ do not need changes. However, $83.32 \%$ of the interviewed lecturers confirmed the importance of lecturer relations in the workplace and only $16.68 \%$ of lecturers are used to working alone.

Within each university, there is a problem with the motivation of lecturers, which has an effect on the productivity of lecturers. Lecturers' motivation is a part of HR science, which analyses the behavior of lecturers in the universities, their strengths and weaknesses, and identifies motivators for the lecturers by encouraging them. And as a result, the productivity of lecturers increases (Wubbolding, 1996). There are various theories to maintain the motivation of lecturers in various fields of activity, but to learn the habits of each lecturer is not for everyone. Often, the needs of lecturers in the universities are not satisfied and, accordingly, this factor is reflected in the drop of the level of Lecturer Productivity. According to Korenková and Urbaníková (2014), the goal of each lecturer is to increase the universities' profits, by achieving success in a certain area. However, only well-motivated lecturers are able to achieve this goal for the universities. Therefore, the attitude to achieve success and the desire to work better for the lecturer is directly proportional to their satisfaction and motivation. For example, according to Zámečník (2014), a study was carried out in Czech and the Slovakian furniture enterprises on the importance of motivational factors for lecturers. Thus, 66 respondents were interviewed and it was revealed that self-sufficiency (i.e. independence) at work and free time was the most important motivator for lecturers; moreover, the salary factor was also allocated. According to Lau and Roopnarain (2014), in the past, managers thought that for the productive work of lecturers, they should only pay a good salary, but there are more factors that affect motivation. Every lecturer should feel part of the system and realize that without them the system will not work.

The problem of Work Life Balance effects on Lecturer Productivity in the universities. According to Haar et al. (2014), lecturers are faced with the problem of achieving a balance between personal life and work, when they can't plan the number of hours needed for work and for private life. This problem covers both single lecturers and lecturers who are married. In this regard, for each lecturer, there is a different balance between work and personal life. Some spend time at work much more than planned or work at home, when at that moment a person needs rest to engage in private life. However, an incorrect approach to this strategy reduces the productivity of lecturers in any universities. Moreover, it is not important whether a person likes his job or not. According to Yadav and Dabhade (2014), women are more serious about the issue of Work Life Balance, because they are mainly educators of the future generation and the governing processes in everyday life. Thus, often, managers exert pressure on lecturers to become workaholics and to neglect their personal lives in job replacements. For example, according to Baptiste et al. (2017), the study of gender differences in the work-life balance in the surgical department of the academic medical center showed that there are more men in this profession than women, but women surgeons are constantly growing.

The problem of leadership certainly stands above all factors affecting the Productivity of Lecturers. According to Burns, (2012), leadership means proper management of personnel and competent thinking in various situations. The most important feature of the leader is the construction of a structure for management, control and improvement of Lecturer Productivity in order to achieve success in the universities. However, in universities, the leadership system is often not built correctly. Lecturers should respect and take an example from their leader, including trust in important matters.

According to Tulu (2017), there is a problem with online social Medias (OSMs) in the workplace, when the Productivity of Lecturers falls, due to the diversion to non-working processes. In this study, 112 respondents were interviewed, who were teachers at Ambo University. The results showed that $63 \%$ of respondents use their accounts in social networks during working hours. However, $49 \%$ of those lecturers who use social networks during working hours have confirmed that they will immediately return to work when necessary, while the remaining $41 \%$ will experience difficulties in this. Thus, it is like two sides of the same coin. On the one hand, lecturers are obliged to carry out the work process and observe the universities' constitution, and on the other hand, lecturers sometimes need to be distracted from work. Thus, finding a compromise between two ways is a problem for the leader.

According to Hanaysha (2016), the competent leader's duties should include intermediate testing of lecturers by identifying competent and incompetent lecturers of the universities to monitor the Productivity of Lecturers. Moreover, leadership means the ability to work with the team and thereby create teams to solve certain tasks together with the help of a brain storming. Often, the lack of training and corporate meetings on which it is possible to identify internal problems and staff issues, affect the decline in Lecturer Productivity.

Professional development and being at the platform of 'state of art' knowledge is a primary concern for the current academics (Koc, 2015, Demirbilek, Yilmaz Ince, 2015). This clearly indicates the importance to identify anteceding factors predicting the lecturers' productivity. Based on the overview, the study aims to examine lecturer work-life balance, responsibility, competency, motivation and professionalism on the lecturer productivity. This study is a quantitative study, these five hypotheses built accordingly. 


\section{Predictors of Productivity}

This study will focus on factors affecting on Lecturer Productivity in the Private universities in the Republic of Kazakhstan. Kazakhstan is chosen as a focus in this research because the state faces the difficulty of Lecturer Productivity, thereby creating a barrier that prevents the increase in the profit and economic situation of the country. In this regard, there are constant crises in the country and the number of unemployed graduates is growing. Despite the fact that there are many factors affecting the productivity of lecturers, this study will focus on the most important of them.

The private universities are good examples for analyzing the Productivity of Lecturers, as these universities provide services for various specializations of students. Thus, the profit of private universities directly depends on the services rendered to students, including further demand for services and cooperation with large world-class corporations. Thus, the private universities in Kazakhstan should be improved to provide the perfect quality of service, through the productive performance of work by the lecturers. Therefore, it is extremely important that this research be done to determine the factors that affecting the Productivity of Lecturers in three private universities namely, Almaty Management University (ALMAU), University of International Business (UIB), and Kazakh University of Management Economics and Prognostication (KIMEP University).

The Government of the Republic of Kazakhstan conducts an active policy of attracting foreign investors for more global development of the Republic, including the establishment of political relations between the countries Kazakhstan Ranking (2016). Given these indicators and strategy, a large number of tourists will come to

\section{'Theory X'}

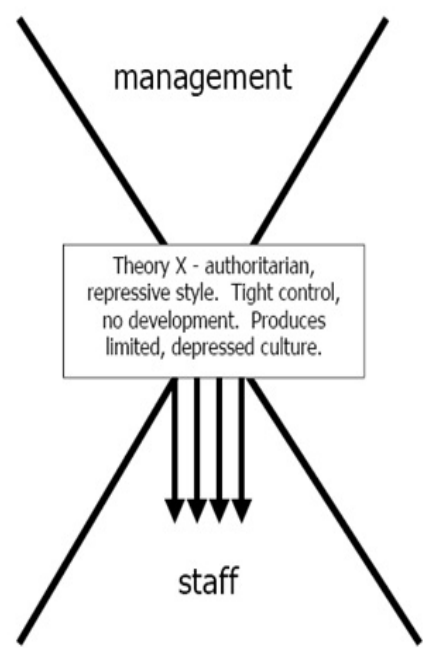

Source: (McGregor, Bennis and Schein, 1983)

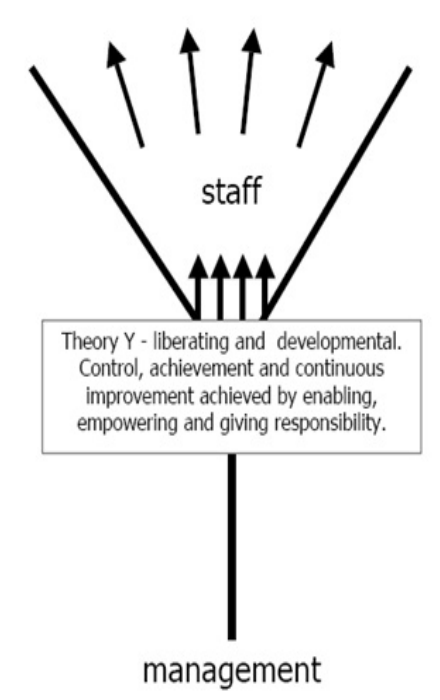

Kazakhstan every year. In consequence of this, it is obligatory to provide a worthy meeting and service because the mood of the guest and the reputation of the State depend on this. In addition, this study can help managers and lecturers of other activities improve the Productivity of Lecturers taking into account the factors that affect this problem.

Each lecturer in the universities has its own work psychology and style of accomplishing the tasks set. In addition, there are absolutely different factors affecting the productivity of each lecturer. Thus, the leader must know the approach to lecturer, studying the strengths and weaknesses of the team's efficiency. In this case, there is a theory of $\mathrm{X}$ and $\mathrm{Y}$, which distinguishes between two categories of building relationships with lecturers to improve the productivity of the universities.

Douglas MacGregor (1906-1964), an American scientist and social psychologist, created the theory of $\mathrm{X}$ and $\mathrm{Y}$. According to McGregor, Bennis and Schein (1983), the theory of $\mathrm{X}$ denotes a rigid authoritarian control regime for lecturers who are lazy but talented. However, the theory of $\mathrm{Y}$ is intended for lecturers who want to work for self-fulfillment and achieve success in the universities.

The main theses of the $\mathrm{X}$ theory include factors such as the average person by nature does not like to work and whenever possible tries to avoid work. Moreover, most people need coercion, strict control, constant management and even intimidation with punishments. Only in this way can they be forced to spend adequate efforts to achieve the goals of the universities where they work. In addition, the average person prefers to be controlled. He seeks to avoid responsibility and has relatively small ambitions, and, above all, he craves security most of all.

\section{'Theory $\mathbf{Y}^{\prime}$}

Figure 1. $\mathrm{X}$ and $\mathrm{Y}$ Theory 
The main theses of the $\mathrm{Y}$ theory include factors, such as strengthening external control and the threat of punishment are not the only means to increase human efforts aimed at achieving the universities goals. If people believe in the tasks assigned to them, they are capable of self-control and self-organization. Furthermore, a person who spends moral and physical forces to work is no less natural than to rest or play. The average person by nature does not feel disgust for work. This means that if it is given the opportunity to fully reveal its potential, it can be stimulated to active and zealous labor activity. Besides that, commitment to goals the result of rewards are clearly linked to the merits of the lecturer. The most significant result of such awards, for example, satisfaction of the need for self-fulfillment are often the direct result of efforts aimed at achieving organizational goals. Moreover, if the right conditions are created, the average person learns not only to take responsibility, but also begins to strive to put it on himself. The desire to avoid responsibility, the lack of ambition and the desire for security are not the natural qualities of people, but acquired experience, as well as ability to exercise a fairly high level of imagination and creativity in solving organizational problems.

Therefore, using this theory, leaders get an opportunity to rationally use the qualities of each lecturer, which influences raising the level of lecturer productivity. Thus, the leader has the opportunity to control the productivity of lecturers within the universities, by analyzing and correctly distributing tasks between lecturers Arslan and Staub (2015). Moreover, the theory of Douglas McGregor explains that within one organization there will be most likely to have both types of lecturers and in this case a successful leader should increase the productivity of lecturers with an individual approach to each lecturer. The theory explains that lecturers of any universities can do much more for these universities if they are treated as valuable and responsible lecturers, thereby increasing the productivity of lecturers. According to Sapience (2017), there is an organization providing services for lecturer productivity analytics, which helps to achieve success in various fields of activity.

\section{Methodology}

The study has taken an approach of quantitative study. The dependent variable is productivity and the independent variable are responsibility, competency, motivation, work-life balance and professionalism investigated as a cross sectional study. Hypotheses are created based on these variables. Data collection was conducted for two months using online questionnaire survey via email. The questionnaire has two sections; demographic profile and the six variable testing. Participants were sent reminders twice in the emails. The research population was lecturers of private universities in Kazakhstan. Sampling design used is simple random sampling based on the sampling of private universities in the south of Republic Kazakhstan in Almaty. Based on the sample size a simple random sampling method used to select the respondents from various universities. Accordingly participants were 130 but 119 were the actual collected. The study outcomes analyses using SPSS version 23. The analysis consists of descriptive analysis and inferential analysis (pearson correlation testing and multiple linear regression). Ethical consideration of the research was firmly considered in providing anonymity and confidentiality of data collection. Besides, consent of respondents was obtained.

\section{Research Findings}

The total number of respondents was 119, of which 67 people (56.3\%) are men and 52 people $(43.7 \%)$ are women, so the number of men is not much more than women. According to the analysis, 61 lecturers $(51.3 \%)$, which is mostly from the respondents, are not married. On the other hand, 50 people $(42 \%)$ are married and try to combine personal life with work. In addition, according to the survey, 8 respondents $(6.7 \%)$ are in divorce. Moreover, none of the respondents is a widow. The survey results show that 33 lecturers $(27.7 \%)$ working in the private universities in Kazakhstan are between the age of 18 and 24. However, the largest number of lecturers $65(54.6 \%)$ are in the age group from 24 to 34 years. In addition, 19 respondents were included in the age group from 35 to 44 years, which makes up $16 \%$ of the total number of respondents. Moreover, 2 people $(1.7 \%)$ were included in the group of people from 45 to 59 years. The study of the level of education showed that 22 lecturers $(18.5 \%)$ completed Diploma, 52 respondents $(43.7 \%)$ have a Bachelor Degree and 45 people (37.8\%) have a Master Degree. Lecturers who completed the PhD were not found. The number of lecturers working in the three universities in the period from 1 month to 1 year was 42 people (35.3\%); in addition, the number of lecturers working in the three universities at the time of the survey was 45 people $(37.8 \%)$. The number of lecturers working from 6 to 11 years in the three universities amounted to 22 people $(18.5 \%)$; moreover, 9 respondents $(7.6 \%)$ work in the three universities in the interval from 11 to 21 years and only 1 of the respondents $(0.8 \%)$ works in the three universities more than 21 years.

Based on Table 1, after factor analysis, some changes happen in the items and some variables need to be renamed accordingly. Initially the independent variable has four dimensions but after factor analysis it became as five dimensions. Based on table 1, factor 1 has 5 items which the significant loadings value falls in between 0.895 and 0.928 , factor 2 has 6 items which the significant loadings value falls in between 0.506 and 0.833 , factor 3 has 3 items which the significant loadings value falls in between 0.693 
and 0.840 , factor 4 has 2 items which the significant loadings value falls in between 0.854 and 0.874 , and factor 5 has 3 items which the significant loadings value falls in between 0.621 and 0.775 . Eigenvalue of these five factors $(5.206,3.680,1.913,1.586,1.262)$ shows more than 1.0. Meanwhile, according to Field (2009) KMO value which falls in between 0.7 and 0.8 are considered as good which reflects in this study whereby the KMO value is 0.793 . Reliability test has been conducted in this study after factor analysis and the value is more than 0.7 which is considered as sufficient based on Nunnally (1981).

Based on factor analysis the hypothesis was changed as follows:

$\mathrm{H}^{1}$ : There is a relationship between Work Life Balance and Lecturer Productivity

$\mathrm{H}^{2}$ : There is a relationship between Responsibility and Lecturer Productivity

$\mathrm{H}^{3}$ : There is a relationship between Competency and Lecturer Productivity

$\mathrm{H}^{4}$ : There is a relationship between Professionalism and Lecturer Productivity

$\mathrm{H}^{5}$ : There is a relationship between Motivation and Lecturer Productivity

Table 1. Factor Analysis

\begin{tabular}{|c|c|c|c|c|c|}
\hline & \multicolumn{5}{|c|}{ Component } \\
\hline & 1 & 2 & 3 & 4 & 5 \\
\hline \multicolumn{6}{|c|}{ Factor 1: Work Life Balance } \\
\hline $\begin{array}{l}\text { The demands of my family or spouse/ partner interfere with work-related } \\
\text { activities. }\end{array}$ & .928 & & & & \\
\hline $\begin{array}{l}\text { I have to put off doing things at work because of demands on my time at } \\
\text { home. }\end{array}$ & .913 & & & & \\
\hline $\begin{array}{l}\text { Things I want to do at work don't get done because of the demands of my } \\
\text { family or spouse/partner. }\end{array}$ & .920 & & & & \\
\hline $\begin{array}{l}\text { My home life interferes with my responsibilities at work such as getting to } \\
\text { work on time, accomplishing daily tasks, and working overtime. }\end{array}$ & .888 & & & & \\
\hline $\begin{array}{l}\begin{array}{l}\text { Family-related strain interferes with my ability to perform job-related } \\
\text { duties. }\end{array} \\
\end{array}$ & .895 & & & & \\
\hline \multicolumn{6}{|c|}{ Factor 2: Responsible } \\
\hline I could be responsible for planning my own work. & & .660 & & & \\
\hline I could make decisions on my own. & & .833 & & & \\
\hline I could be free to use my judgments. & & .763 & & & \\
\hline I could have a very responsible job. & & .739 & & & \\
\hline I try to think if ways of doing my job effectively. & & .506 & & & \\
\hline $\begin{array}{l}\text { I think the lecturers of the university I work for are highly involved in } \\
\text { decision making at work. }\end{array}$ & & .634 & & & \\
\hline \multicolumn{6}{|c|}{ Factor 3: Competency } \\
\hline $\begin{array}{l}\text { If there is a training opportunity, the management of the university I work } \\
\text { for usually encourages the lecturers to participate. }\end{array}$ & & & .840 & & \\
\hline $\begin{array}{l}\text { I think the training provided by the university I work for can meet the } \\
\text { demands of the lecturers. }\end{array}$ & & & .828 & & \\
\hline $\begin{array}{l}\text { The university I work for would communicate with its lecturers regarding } \\
\text { their achievements and offer them suggestions. }\end{array}$ & & & .693 & & \\
\hline \multicolumn{6}{|c|}{ Factor 4: Professionalism } \\
\hline My opinion of myself goes down when I do the job badly. & & & & .875 & \\
\hline I feel unhappy when my work is not up to my usual standard. & & & & .854 & \\
\hline \multicolumn{6}{|c|}{ Factor 5: Motivation } \\
\hline I take pride in doing my job as well as I can. & & & & & .648 \\
\hline I like to look back at a day's work with a sense of a job well done. & & & & & .775 \\
\hline $\begin{array}{l}\text { Compared with other companies in the same field, I think the salary and } \\
\text { welfare offered by the university I work for are better. }\end{array}$ & & & & & .621 \\
\hline Eigenvalue & 5.206 & 3.680 & 1.913 & 1.586 & 1.262 \\
\hline$\%$ of variance explained & 26.028 & 18.398 & 9.567 & 7.932 & 6.309 \\
\hline Cronbach's alpha & .952 & .817 & .784 & .811 & .797 \\
\hline KMO & \multicolumn{3}{|c|}{.793} & & \\
\hline Bartlett's Test of Sphericity & \multicolumn{3}{|c|}{1284.467} & & \\
\hline
\end{tabular}


Table 2. Correlation Analysis

\begin{tabular}{|c|c|c|c|c|c|c|c|}
\hline \multicolumn{8}{|c|}{ Correlations } \\
\hline & & $\begin{array}{c}\text { Lecturer } \\
\text { Productivity }\end{array}$ & $\begin{array}{c}\text { Work Life } \\
\text { Balance }\end{array}$ & Responsible & Competency & Professionalism & Motivation \\
\hline \multirow{3}{*}{ Lecturer Productivity } & Pearson Correlation & 1 & $.989 * *$ & $.268^{* *}$ & .081 & -.094 & $-.210^{*}$ \\
\hline & Sig. (2-tailed) & & .001 & .003 & .384 & .309 & .022 \\
\hline & $\mathrm{N}$ & 119 & 119 & 119 & 119 & 119 & 119 \\
\hline \multirow{3}{*}{ Work Life Balance } & Pearson Correlation & .001 & 1 & .124 & .120 & $-.198^{*}$ & $.198^{*}$ \\
\hline & Sig. (2-tailed) & .989 & & .179 & .193 & .031 & .031 \\
\hline & $\mathrm{N}$ & 119 & 119 & 119 & 119 & 119 & 119 \\
\hline \multirow{3}{*}{ Responsible } & Pearson Correlation & $.268^{* *}$ & .124 & 1 & $.450^{* *}$ & -.166 & $.249^{* *}$ \\
\hline & Sig. (2-tailed) & .003 & .179 & & .000 & .070 & .006 \\
\hline & $\mathrm{N}$ & 119 & 119 & 119 & 119 & 119 & 119 \\
\hline \multirow{3}{*}{ Competency } & Pearson Correlation & .081 & .120 & $.450^{* *}$ & 1 & .013 & $.191^{*}$ \\
\hline & Sig. (2-tailed) & .384 & .193 & .000 & & .891 & .038 \\
\hline & $\mathrm{N}$ & 119 & 119 & 119 & 119 & 119 & 119 \\
\hline \multirow{3}{*}{ Professionalism } & Pearson Correlation & -.094 & $-.198^{*}$ & -.166 & .013 & 1 & -.045 \\
\hline & Sig. (2-tailed) & .309 & .031 & .070 & .891 & & .627 \\
\hline & $\mathrm{N}$ & 119 & 119 & 119 & 119 & 119 & 119 \\
\hline \multirow{3}{*}{ Motivation } & Pearson Correlation & $-.210^{*}$ & $.198^{*}$ & $.249^{* *}$ & $.191^{*}$ & -.045 & 1 \\
\hline & Sig. (2-tailed) & .022 & .031 & .006 & .038 & 627 & \\
\hline & $\mathrm{N}$ & 119 & 119 & 119 & 119 & 119 & 119 \\
\hline \multicolumn{8}{|c|}{$* *$. Correlation is significant at the 0.01 level (2-tailed). } \\
\hline \multicolumn{8}{|c|}{ *. Correlation is significant at the 0.05 level (2-tailed). } \\
\hline
\end{tabular}

Based on table 2 correlation analysis, it shows that lecturer productivity shows very low correlation with work life balance (.001), low correlation with responsible $\left(.268^{* *}\right)$, very low correlation with competency $(.081)$, very low correlation with professionalism (-.094) and low correlation with motivation $\left(-.210^{*}\right)$. Next, work-life balance shows very low correlation with responsible $(.124)$, very low correlation with competency $(.120)$, very low correlation with professionalism $\left(-.198^{*}\right)$, very low correlation with motivation $\left(.198^{*}\right)$. Responsibility shows moderate correlation with competency $\left(.450^{* *}\right)$, low correlation with professionalism (-.166), low correlation with motivation $\left(.249^{* *}\right)$. Competency shows very low correlation with professionalism (.013), very low correlation with motivation $\left(191^{*}\right)$. Meanwhile, professionalism shows very low correlation with motivation (-.045).

Based on table 3 multiple regression analysis, model 1 age and experience is a control variable with (0.042) $4.2 \%$ having low $\mathrm{R}$ square compared to model 2 with experience, age, professionalism, motivation, competency, work life balance and responsible with (0.164) 16.4\%. Independent variable of total variation of Model 2 explains $16.4 \%$ of total variation of lecturer productivity. The study from ANOVA table shows, control variable is not significant
(0.082) because it is more than 0.05 but model 2 is significant with 0.005 . Therefore model 2 is fit in this study and it is not controlled by experience and age. Coefficient table results have significant in some variable only. $\beta$ value with significant of age, experience, work life balance, responsible, competency, professionalism and motivation is $0.074(0.342),-0.031(0.576), 0.001 \quad(0.979), 0.279$ (0.005), -0.021 (0.838), $-0.033(0.610)$ and $-0.248(0.003)$ respectively. It shows that only two variables are significant in this model which is responsible and motivation toward lecturer productivity. Responsibility has low positive $(0.279)$ relationship and motivation has low negative $(-0.248)$ relation towards lecturer productivity. The multicollinearity (VIF) for this model is in satisfactory situation since all the VIF value is less than five. This shows there is no multicollinearity in this model. The model for this study is:

Lecturer productivity $=3.171+0.279$ Responsibility -0.248 Motivation

Lecturer productivity will increase by 0.279 when one unit increases in responsible whereas lecturer productivity will decrease by 0.248 when one unit increases in motivation while other variables remain constant. This shows that lecturer productivity can be measured by responsibility and motivation only. 
Table 3. Multiple Regression Analysis

\begin{tabular}{|c|c|c|c|c|c|c|c|c|c|c|c|c|}
\hline \multicolumn{13}{|c|}{ Model Summary } \\
\hline Model & $\mathrm{R}$ & R Squar & \multicolumn{4}{|c|}{ Adjusted R Square } & \multicolumn{6}{|c|}{ Std. Error of the Estimate } \\
\hline 1 & $.206^{\mathrm{a}}$ & .042 & \multicolumn{4}{|c|}{.026} & \multicolumn{6}{|c|}{.45198} \\
\hline 2 & $.404^{\mathrm{b}}$ & .164 & \multicolumn{3}{|c|}{.111} & \multicolumn{7}{|c|}{.43180} \\
\hline \multicolumn{13}{|c|}{ a. Predictors: (Constant), Experience, Age } \\
\hline \multicolumn{13}{|c|}{ b. Predictors: (Constant), Experience, Age, Professionalism, Motivation, Competency, Work-Life Balance, Responsible } \\
\hline \multicolumn{13}{|c|}{ ANOVA $^{\mathrm{a}}$} \\
\hline \multicolumn{2}{|r|}{ Model } & \multicolumn{2}{|c|}{ Sum of Squares } & \multicolumn{2}{|r|}{$\mathrm{df}$} & \multicolumn{5}{|c|}{ Mean Square } & $\mathrm{F}$ & Sig. \\
\hline \multirow{3}{*}{1} & Regression & \multicolumn{2}{|c|}{1.045} & \multicolumn{2}{|r|}{2} & \multicolumn{5}{|c|}{.523} & 2.559 & $.082^{\mathrm{b}}$ \\
\hline & Residual & \multicolumn{2}{|c|}{23.697} & \multicolumn{2}{|r|}{116} & \multicolumn{5}{|c|}{.204} & & \\
\hline & Total & \multicolumn{2}{|c|}{24.743} & & 118 & & & & & & & \\
\hline & Regression & & & & 7 & & & & .578 & & 3.101 & $.005^{\mathrm{c}}$ \\
\hline 2 & Residual & & & & 111 & & & & .186 & & & \\
\hline & Total & & & & 118 & & & & & & & \\
\hline & & & a. De & ende & nt $\mathrm{Va}$ & able: Lect & rer $\operatorname{Pr}$ & duct & & & & \\
\hline & & & b. P & dict & ors: ( & onstant), E & perie & $\mathrm{ce}, A$ & & & & \\
\hline & c. Predictors: (Co & astant), Exp & ence, Age & Profe & ession & ism, Moti & ation, & Com & etency, & ork Life Ba & ce, Responsible & \\
\hline & & & & & & efficients & & & & & & \\
\hline & Model & Unstandar & ed Coeffic & & & $\begin{array}{l}\text { dardized } \\
\text { fficients }\end{array}$ & $\mathrm{t}$ & & Sig. & & linearity Statisti & \\
\hline & & $\mathrm{B}$ & Std. E & & & Beta & & & & Tolerance & VIF & \\
\hline & (Constant) & 3.046 & .122 & & & & 24. & & .000 & & & \\
\hline 1 & Age & .170 & .07 & & & 262 & 2.2 & & .026 & .611 & 1.637 & \\
\hline & Experience & -.071 & .05 & & & .149 & -1.2 & & .203 & .611 & 1.637 & \\
\hline & (Constant) & 3.171 & .57 & & & & 5.5 & & .000 & & & \\
\hline & Age & .074 & .078 & & & 115 & .9 & & .342 & .518 & 1.931 & \\
\hline & Experience & -.031 & .05 & & & .066 & -.5 & & .576 & .551 & 1.815 & \\
\hline v & Work Life Balance & .001 & .04 & & & 002 & .02 & & .979 & .824 & 1.214 & \\
\hline 2 & Responsible & .279 & .098 & & & 307 & 2.8 & & .005 & .650 & 1.539 & \\
\hline & Competency & -.021 & .102 & & & .020 & -.2 & & .838 & .757 & 1.320 & \\
\hline & Professionalism & -.033 & .06 & & & .046 & -.5 & & .610 & .926 & 1.080 & \\
\hline & Motivation & -.248 & .08 & & & .285 & -3.0 & & .003 & .881 & 1.135 & \\
\hline & & & a. De & ende & nt $\mathrm{Va}$ & able: Lect & rer $\operatorname{Pr}$ & duct & & & & \\
\hline & & & & & Excl & led Varia & $\operatorname{les}^{\mathrm{a}}$ & & & & & \\
\hline & Model & Beta In & t & & io & Parti & & & & Collineari & Statistics & \\
\hline & Miodel & Beta in &  & & Ig. & Correla & & & erance & VIF & Minimum Tole & ance \\
\hline & Work Life Balance & $-.026^{b}$ & -.270 & & 787 & -.02 & & & 377 & 1.140 & .583 & \\
\hline & Responsible & $.228^{\mathrm{b}}$ & 2.346 & & 021 & .21 & & & 345 & 1.184 & .530 & \\
\hline 1 & Competency & $.043^{\mathrm{b}}$ & .458 & & 648 & .04 & & & 60 & 1.041 & .587 & \\
\hline & Professionalism & $-.076^{b}$ & -.823 & & 412 & -.07 & & & 975 & 1.026 & .606 & \\
\hline & Motivation & $-.216^{\mathrm{b}}$ & -2.389 & & 019 & -.21 & & & 971 & 1.030 & .598 & \\
\hline & & & a. $\mathrm{De}$ & ende & $\mathrm{nt} \mathrm{Va}$ & able: Lect & er $\operatorname{Pr}$ & duct & & & & \\
\hline & & & b. Predicto & in $\mathrm{t}$ & he $\mathrm{M}$ & el: (Const & $n t), E$ & peri & hce, Age & & & \\
\hline
\end{tabular}




\section{Conclusions}

The regression model and correlation analysis through Pearson Product Moment correlation coefficient applied to test the significance of relationship between five independent variables and dependent variables. The independent variables included were work life balance, responsibility, competency, professionalism and motivation. The lecturer productivity is the dependent variable. Results have shown weak relationship with all independent variables. Motivation and professionalism variables indicate very negative relationship. Increase in work life balance, competency and responsibility were correlated with the increase of level lecturers productivity. Adversely, decrease in professionalism and motivation were correlated with increases in level of lecturer productivity. Conclusively, this indicates all tested variables somewhat have the relationship with lecturer productivity though it is a weak relationship. These results support the hypotheses and objective of the study. The objective is met in testing the relationship of the variables on lecturers' productivity.

Based on the multiple regression analysis, responsibility and motivation contributes to the regression weight which is statistically significant at $p<0.05$. Therefore only these variables make meaning to the regression model.

This study was to find a significant relationship between lecturer productivity and lecturer motivation. Thus, on the basis of the results of this study, it can be seen that the hypothesis shows a significant negative relationship between lecturer productivity and lecturer motivation. Moreover, according to a study conducted by Vogel, Homberg and Gericke (2016), in order to raise the level of lecturer productivity, it is necessary to increase the motivation and desire of lecturers to make profit for the universities, in which it operates. It's not a secret that properly and sufficiently motivated lecturers are able to complete the tasks assigned to them earlier and better, in comparison with non-motivated lecturers. In addition, according to research by Liu and Li (2017), one of the types of motivation is material motivation, which directly has effects on lecturer productivity at the workplace by raising the personal mood and feeling in the reliability of his person. Moreover, according to Ugaddan and Park, (2017), the research shows that the main goal of motivation is to improve lecturer productivity in the workplace.

Thus, the results of the study and the hypothesis indicated that there is positive relationship between lecturer productivity and work life balance. The reason was that a large percentage of respondents $(56.3 \%)$ are men; in addition, the percentage of single respondents was $51.3 \%$. Thus, respondents who do not have a family do not believe that there is a positive relationship between work-life balance and lecturer productivity. In addition, given the mentality of Kazakhstan, men do not have to take responsibility for cooking at home, raising children, cleaning the house, etc. because this is part of women's responsibilities. In addition, according to Ansari et al. (2015), the researcher confirms that not all components of the work life balance affect lecturer productivity, such as flexible working hours. Nevertheless, in contrast to this study, according to Bui, Liu and Footner (2016), the researcher found a positive relationship between lecturer productivity and balance and indicates that people with the right balance between personal life and work perform task better, thereby raising their productivity level.

Thus, the results of the study on the hypothesis indicates that a positive relationship between lecturer productivity and responsibility. Job role and responsibility tends to give empowerment. As such, productivity of a lecturer increases. Van De Voorde, Veld \& Veldhoven (2016) have identified an explicit relationship between empowerment and productivity. Competency has been also able to create more flexible and mobile labour force.

Based on the findings of the study, professionalism has got a positive and significant relationship with lecturer productivity. In literature, professional behaviour affects job satisfaction (Celik \& Hisar, 2012; Paoline \& Lambert 2012) and thus influences job performance of a lecturer (Chen, et al., 2012).

The results based on relationship between lecturer productivity and competency supports the hypothesis. Competency plays a vast role in supporting lecturers' performance and on the whole and decades of studies emphasised the importance of competency (Windsor, Douglas \& Harvey, 2012).

The scope of this research was limited to five variables. Further, studies need to analyse and measure effect of other variables on productivity. Since the $\mathrm{R}^{2}$ accounts for low lecturer productivity variance, extended research needs to be done to close the gap. On the other hand, productivity is a very wide concept to study. A comparative analysis is recommended within the private universities in Kazakhstan ranging from higher star to lower star rating. Sample size in this study was small, suggesting widening the sample range in longer time period with different auxiliary variables.

The findings of this research have shown the significance of work-life balance, responsible, competency, professionalism and motivation. This raises question to individual characteristics of some countries that have different universities policies. A question on economy and political factor may need to be examined in future. This query arises as the variables tested indicate reverse result than the literature.

This study can help academic researchers to realize the consistency of the impact of the work-life balance, responsible, competency, professionalism and motivation with the theory and the results of past literature. Additionally, the research can be applied for further research and expand upon the findings of this research in Kazakhstan. A research linked with moderating variables e.g. job satisfaction, empowerment which has been also 
elaborated in past literature can be linked to lecturer productivity. This certainly gives a wider opening to the context of this research.

The empirical result shows that appropriate policy in high performance work system implied in increasing the level of lecturer productivity. Therefore, efforts should be made to improve the lecturer assistance program and benefits like flexible work hours and job design and to create professionalism.

In addition, results also indicate negative relationship between motivation and lecturer productivity which is adversely reported from the literature. This could indicate that lecturers aren't on the motivated ground to test the level of motivation. On the other theoretical concern measurement of motivation may not be reliable for this context. Professionalism which reported to have negative relationship may depend on the universities structure that works indifferently in Kazakhstan private universities. Hence, universities human resource experts need to look into policy making that enhanced the strategic human resource management. There is indeed a need to have an extensive study on these variables to confirm the results on a longer and wider research mode.

\section{REFERENCES}

[1] Azam, M. et al., 2011. Institutions, macroeconomic policy and foreign direct investment: South Asian countries case. African Journal of Business Management, 5(11), pp. 4306-4313.

[2] Barassi, M. R. \& Zhou, Y., 2012. The effect of corruption on FDI: A parametric and non-parametric analysis. European Journal of Political Economy, 28(3), pp. 302-312.

[3] Bartels, F. L., Napolitano, F. \& Tissi, N. E., 2014. FDI in Sub-Saharan Africa: A longitudinal perspective on location-specific factors (2003-2010). International Business Review, 23(3), p. 516-529.

[4] Bayar, G., 2011. Causes of corruption: Dynamic panel data analysis of some Post - Soviet countries and East Asian countries. Journal of Applied Business Research, 27(1), p. $77-86$.

[5] Boateng, A., Hua, X., Nisar, S. \& Wu, J., 2015. Examining the determinants of inward FDI: Evidence from Norway. Economic Modelling, 47(1), p. 118-127.

[6] Chen, Z., Sun, H., Lam, W., Hu, Q., Huo, Y. and Zhong, J.A., 2012. Chinese hotel employees in the smiling masks: Roles of job satisfaction, burnout, and supervisory support in relationships between emotional labor and performance. The International Journal of Human Resource Management, 23(4), pp.826-845.

[7] Çelik, S. and Hisar, F., 2012. The influence of the professionalism behaviour of nurses working in health institutions on job satisfaction. International Journal of Nursing Practice, 18(2), pp.180-187.
[8] Cuervo-Cazurra, A., 2008. Better the Devil You Don't Know: Types of Corruption and FDI in Transition Economies. International Business and Institutional Development in Central and Eastern Europe, 14(1), pp. 12-27.

[9] Drury, A. C., Krieckhaus, J. \& Lusztig, M., 2006. Corruption, Democracy, and Economic Growth. International Political Science Review, 27(2), pp. 121-136.

[10] Dutta, N. \& Roy, S., 2011. Foreign Direct Investment, Financial Development and Political Risks. The Journal of Developing Areas, 44(2), pp. 303-327.

[11] Elfakhani, S. \& Mackie, W., 2015. An analysis of net FDI drivers in BRIC countries. Competitiveness Review, 25(1), pp. 98-132.

[12] Financial Times, 2006. Ask the expert: BRICs and investor strategy. [Online] Available at: https://www.ft.com/content /c8192f64-6a66-11db-83d9-0000779e2340 [Accessed 1 July 2017].

[13] Freckleton, M., Wright, A. \& Craigwell, R., 2012. Economic growth, foreign direct investment and corruption in developed and developing countries. Journal of Economic Studies, 39(6), pp. 639-652.

[14] Ghosh, I., 2007. The Relation between Trade and FDI in Developing Countries -- A Panel Data Approach. Global Economy Journal, 7(3), pp. 50-62.

[15] Goswami, G. G. \& Haider, S., 2014. "Does political risk deter FDI inflow? An analytical approach using panel data and factor analysis. Journal of Economic Studies, 41(2), pp. 233-252.

[16] Güriş, S. \& Gözgör, K., 2015. Trade Openness and Fdi Inflows in Turkey. Applied Econometrics and International Development, 15(2), pp. 53-62.

[17] Hakkala, K., Norback, P. \& Svaleryd, H., 2008. Asymmetric effects of corruption on FDI: evidence from Swedish multinational firms. The Review of Economics and Statistics, 90(1), pp. 627-642.

[18] Hakro, A. N. \& Ghumro, I. A., 2011. Determinants of Foreign Direct Investment Flows to Pakistan. The Journal of Developing Areas, 44(2), pp. 217-242.

[19] Hayat, A. \& Cahlik, T., 2017. FDI and Economic Growth: A Changing Relationship across Country and Over Time. Munich Personal RePEc Archive, 10 April, pp. 1-21.

[20] Helmy, H. E., 2013. The impact of corruption on FDI: is MENA an exception? International Review of Applied Economics, 27(4), pp. 491-514.

[21] Huang, C.-J., 2016. Is corruption bad for economic growth? Evidence from Asia-Pacific countries. North American Journal of Economics and Finance, Volume 35, p. 247-256.

[22] Iloie, R. E., 2015. Connections between FDI, Corruption Index and Country Risk Assessments in Central and Eastern Europe. Procedia Economics and Finance, 32(1), p. $626-$ 633.

[23] Javorcik \& Wei, 2009. Corruption and cross-border investment in emerging markets: firm-level evidence. Journal of International Money and Finance, 28(1), pp. 605-624. 
[24] Khandaker, S. \& Sharmin, R., 2015. The Determinant of Foreign Direct Investments, Evidence from Bangladesh. Global Review of Accounting and Finance, 6(2), pp. 82-97.

[25] Koc, M. Demirbilek, M \& İnce, E. Y.(2015). A Needs Assessment for Academicians' Professional Development. Education \& Science/Egitim ve Bilim, 40(177), 297-311.

[26] Kosekahyaoglu, L., 2006. A comparative analysis of FDI in Turkey and the CEECs: Is there any link between FDI and trade? Journal of Business Economics and Management, 7(4), pp. 183-200.

[27] Lucke, N. \& Eichler, S., 2016. Foreign direct investment: the role of institutional and cultural determinants. Applied Economics, 48(11), p. 935-956.

[28] Mora, J. \& Singh, N., 2013. Trade productivity upgrading, trade fragmentation, and FDI in manufacturing: The Asian development experience. Indian Growth and Development Review, 6(1), pp. 61-87.

[29] Mudambi, R., Navarra, P. \& Delios, A., 2013. Government regulation, corruption, and FDI. Asia Pacific journal of management, 30(2), pp. 487-511.

[30] Nunnally, J.C. (1981). Psychometric theory. (2nd Ed). New Delhi: Tata McGraw-Hill publishing Co Ltd.

[31] O'Neill, S., 2017. American Airlines Expects to Catch Up to Delta With Its Basic Economy Strategy. [Online] Available at: https://skift.com/2017/01/27/american-airlines-expectsto-catch-up-to-delta-with-its-basic-economy-strategy/[Acc essed 26 March 2017].

[32] Pattayat, S. S., 2016. Examining the determinants of FDI inflows in India. Theoretical and Applied Economics, 23(2), pp. 225-238.

[33] Pegkas, P., 2015. The impact of FDI on economic growth in Eurozone countries. The Journal of Economic Asymmetries, 12(2), pp. 124-132.

[34] Paoline, E.A. and Lambert, E.G., 2012. The issue of control in jail: The effects of professionalism, detainee control, and administrative support on job stress, job satisfaction, and organizational commitment among jail staff. American Journal of Criminal Justice, 37(2), pp.179-199.

[35] Rashid, M., Looi, X. H. \& Jye, W. S., 2017. Political stability and FDI in the most competitive Asia Pacific countries. Journal of Financial Economic Policy, 9(2), pp. $1-19$.

[36] Rawlings, J. O., Pantula, S. G. \& Dickey, D. A., 1998. Applied Regression Analysis: A Research Tool. 2nd ed. New York: Springer.

[37] Shahzad, A. \& Al-Swid, A. K., 2013. Effect of Macroeconomic Variables on the FDI inflows: The Moderating Role of Political Stability: An Evidence from Pakistan. Asian Social Science, 9(9), pp. 270-279.

[38] Shahzad, A., Mithani, D. A., Al-Swidi, A. K. \& Fadzil, F. H. B., 2012. Political Stability and the Foreign Direct Investment Inflows in Pakistan. British Journal of Arts and Social Sciences, 9(2), pp. 199-213.

[39] Stack, M. M., Ravishankar, G. \& Pentecost, E., 2017. Foreign direct investment in the eastern European countries: Determinants and performance. Structural Change and
Economic Dynamics, 41(1), p. 86-97.

[40] Touny, M. A., 2016. The interactive effects of corruption and political instability on foreign direct investment: evidence from the Middle East region. Int. J. Trade and Global Markets, 9(4), pp. 370-385.

[41] Van De Voorde, K., Veld, M., \& Van Veldhoven, M. (2016). Connecting empowerment-focused HRM and labour productivity to work engagement: the mediating role of job demands and resources. Human Resource Management Journal, 26(2), 192-210.

[42] Waugh, M. E. \& Ravikumar, B., 2016. Measuring openness to trade. Journal of Economic Dynamics and Control, 72(1), p. 29-41.

[43] Windsor, C., Douglas, C. and Harvey, T., 2012. Nursing and competencies-a natural fit: the politics of skill/competency formation in nursing. Nursing inquiry, 19(3), pp.213-222.

[44] World bank Group, 2017. Political Stability and Absence of Violence/Terrorism. [Online] Available at: http://info.worl dbank.org/governance/wgi/pdf/pv.pdf 